\title{
Strontium isotopic geochemistry of Pan-African/Brasiliano rocks, Chapada copper deposit, Goiás, Brazil
}

\author{
By Stephen V. Richardson, Ann Arbor, Lois, M. Jones, Ponca City and STEPHeN E. Kesler, Ann Arbor*) \\ With 2 figures and 1 table
}

\section{Zusammenfassung}

Das Trägergestein der Chapada Kupferlagerstätte in Goiás ist in metamorpher Hoch-Amphibolitfazies ausgebildet. Gesamtgesteins- und individuelle Mineral Rb-Sr-Isochronen mit einem ${ }^{87} \mathrm{Sr}_{\mathrm{r}} /{ }^{86} \mathrm{Sr}$-Initialwert (I) von $0,70414 \pm 0.00005$ ergeben für die Kristallisation der Vulkanite und Magmatite, die die Metamorphose vordatieren, ein Alter von $561 \pm 9$ Mio Jahre. Die Datierung der Metamorphose während der panafrikanisch/brasilianischen Orogenese $(700$ bis 450 Mio Jahre) ergibt $532 \pm 1$ Mio Jahre. Das Mineral-Isochronenalter eines Dioritkörpers porphyrischen Gefüges, der in die Schiefer intrudierte, beträgt $534 \pm 16$ Mio Jahre (I = 0,70415 \pm 0,00004). Das Ergebnis niedriger Initial-Werte dieser Isochronen ergibt für die Schiefer bei Chapada ein AusgangsMaterial im Bereich des oberen Mantels oder der tieferen Kruste; diese Ausgangswerte sind charakteristisch für magmatische Tätigkeit in Verbindung mit Inselbögen. Das unterkambrische Alter des Trägergesteins bei Chapada steht im Widerspruch zu dem bisher angenommenen mittelproterozoischen Alter und ist ein Hinweis auf eine mögliche Phase intensiverer pan-afrikanisch/brasilianischer magmatischer Aktivität in Zentral-Brasilien als ursprünglich angenommen wurde.

\section{Abstract}

Whole rock and mineral $\mathrm{Rb}$-Sr isochrons from the upper amphibolite grade metamorphic host rocks of the Chapada copper deposit in Goias, Brazil, yield an age of $561 \pm 9 \mathrm{Ma}$, with $a^{87} \mathrm{Sr} /{ }^{86} \mathrm{Sr}$ initial (I) of $0.70414 \pm 0.00005$, for the crystallization of pre-metamorphic volcanic and igneous rocks and 532 $\pm 1 \mathrm{Ma}$ for their metamorphism during the PanAfrican/Brasiliano orogeny (700-450 Ma). A porphyritic diorite stock which intruded the host schists yields a mineral isochron age of $534 \pm 16 \mathrm{Ma}(\mathrm{I}=0.70415 \pm 0.00004)$. The low I values determined from these isochrons suggest that the host schists at Chapada were derived from upper mantle or lower crust material and are characteristic of magmatic products associated with island arcs. The Early Cambrian age of the host rocks at Chapada contradicts the previously assigned mid-Proterozoic age and suggests that Pan-African/Brasiliano

\footnotetext{
*) Authors' addresses: St. V. RICHAROSON and St. E. KESLER, Department of Geological Sciences, University of Michigan, Ann Arbor, MI 48109, USA and L. M. JONES, Research and Development Dept., CONOCO, Inc., P. O. Box 1267, Ponca City, OK 74603.
}

magmatic activity may have been more extensive in central Brazil than previously thought.

\section{Résumé}

Les roches qui contiennent le gisement de cuivre de Chapada (Goias, Brésil) sont des schistes cristallins appartenent au facies dupérieur des amphibolites. Dans des volcanites et des roches orthomagmatiques appartenant à cet ensemble, des isochrones $\mathrm{Rb}-\mathrm{Sr}$ sur roches totales et sur minéraux donnent un âge de $561 \pm 9 \mathrm{Ma}$ avec un rapport initial de 0,70414 \pm 0,00005 pour la cristallisation pré-métamorphique et un âge de $532 \pm 1$ Ma pour le métamorphisme, lié à l'orogenèse pan-africaine / brésilienne. Un pluton de diorite porphyrique, qui intrude les schistes cristallins donne, par isochrone sur minéraux, un âge de $534 \pm 16 \mathrm{Ma}$ (rapport initial de 0,70415 \pm 0,00004 ). Les valeurs basses des rapports initiaux de ces diverses roches suggèrent que les schistes de Chapada sont dérivés de matériaux mantelliques ou crustaux profonds et présentent les caractères des produits magmatiques associés aux arcs insulaires. Leur âge éo-cambrien, en contradiction avec l'âge mésoprotérozoïque admis jusqu'ici, permet de penser que l'activité magmatique pan-africaine/brésilienne dans le centre du Brésil a été plus intense que ce qu'on croyait jusqu'ici.

\section{Краткое содержание}

Вмещающие породы залежи меди Chapada в Goiás представляют собой амфиболитовую фапию высшей степени метаморфизма. Цельная порода и отдельнье минералы дают для кристаллизации вулканитов и магматитов до метаморфизма начальное значение соотношения стронция в $0,70414 \mp 0,00005$, что разрешает цринять их возраст в $561 \mp 9$ Мио лет, а возраст метаморфизма в 532 Ғ 1 Мио, т. е. отнести его к периоду панафриканского -бразильского орогенеза / 700 до 450 Мио /. При определении возраста минералов из диоритных тел порфиритовых текстур, интрудированньх в сланец, получили даты в $534 \mp 16$ Мио лет / $1=$ $0,70415=0,00004 /$. Такое низкое значение исходных величин соотношения изотопов разрешает предполагать, что материал для Chapada принесен был из мантии, или глубинных регионов коры. Эти исходные значения характерны для магматической деятельности типа островных дуг. Возраст вмещающих пород считают средне-протерозойским; это стоит в противоре- 
чии с новейшими данными, по которым он может быть только нижнекембрийским. Это также указьгает на то, что фаза пан-африканско-бразильской магматической активности в центральной Бразилии протекала, возможно, гораздо интенсивнее, чем принимали это до сих пор.

\section{Introduction}

This study presents strontium isotopic data from the Chapada copper deposit in central Brazil that document magmatic activity related to the PanAfrican/Brasiliano orogenic event $(700-450 \mathrm{Ma})$. This research is an outgrowth of a detailed study of the Chapada copper deposit (RICHARDSON et al., 1986) which, prior to our work, was thought to be of midProterozoic age (RIBEIRO FILHO, 1981). While the principal focus of our investigation of the Chapada deposit has been elucidation of its origin and geochemistry, rather than clarification of its regional setting and timing of emplacement, we present these data in the hope that they will aid in the effort to delineate areas of Pan-African/Brasiliano rocks in central Brazil.

\section{Geologic Setting and Characteristics of the Chapada Deposit}

Chapada lies in the Brasilia-Uruacu mobile belt, which forms part of the Tocantins province between the Guaporé and São Francisco cratons. This mobile belt is geologically complex and contains rocks of Archean to Paleozoic age (DANNI et al., 1982; BERNASCONI, 1983). The principal stratigraphic divisions determined by regional mapping and radiometric dating in the Chapada region are: (1) Archean granitegneiss, (2) Archean greenstone, (3) Early to Mid-Proterozoic metavolcanic and metasedimentary rocks (RrBEIRO FILHO, 1981). Archean granite-gneiss and greenstone constitute the Goiás Central Massif, the basement upon which younger units have developed. Chapada itself is on the flank of the Hidrolina Dome, an Archean granitic block belonging to the Goiás Central Massíf (Fig. 1).

Our geological, mineralogical, and geochemical data on the Chapada deposit indicate that it is a metamorphosed wallrock-hosted porphyry copper deposit (RICHARDSON et al., 1986). Analogous porphyry $\mathrm{Cu}$ Mo-Au deposits, some of which are metamorphosed, are found in terranes of Archean age in Canada, W. Australia, and Zambia (WAKEFIELD, 1978; AYRES 8 \& CERNY, 1982; BARLEY, 1982), of Proterozoic age in Finland (GAAL \& ISOHANNI, 1979), of Devonian age in Scotland (FORTEY, 1980). Mineralization at Chapada is found as disseminated chalcopyrite and pyrite hostes primarily by biotite schist that is in- terlayered with lesser amounts of muscovite schist, amphibolite, and feldspathic quarzite. These rocks have been regionally metamorphosed to the upper amphibolite facies $\left(650 \pm 20^{\circ} \mathrm{C}, 9 \pm \mathrm{kb}\right.$; RICHARDSON et al., 1986).

Mineralization clearly occurred prior to metamorphism as indicated by foliated sulfide minerals, sulfide inclusions in metamorphic minerals, evidence of sulfide-wall rock interaction such as zincian staurolite and gahnite, and the sensitivity of iron contents of biotite to $\mathrm{fO}_{2}$ conditions dictated by accompanying sulfide-oxide mineral assemblages. Field relations, isotopic data discussed in this paper, and petrochemistry indicate that the host schists at Chapada were calcalkaline, peraluminous basaltic andesites to andesites of island arc affiliation. These rocks were intruded by a petrologically similar porphyritic diorite stock now separated from the Chapada deposit by a mylonite zone (RICHARDSON et al., 1986, Fig. 3). Mica-amphibole schists within the deposit are considered metamorphosed hydrothermally altered equivalents of this diorite.

In the Chapada region, greenstone sequences have been designated as the Pilar de Goias Group and are thought to be Archean in age because of their inclusion as xenoliths within radiometrically dated Archean granitoids (RIBEIRO FILHO, 1981). The rocks hosting the Chapada deposit have been designated the Mara Rosa Sequence and unconformably overlie or are thrust over the Archean Pilar de Goiás Group (Fig. 1). They have been considered early to mid-Proterozoic in age, based on their position immediately above Archean basement rocks (RIBEIRO FILHO, 1981). The Mara Rosa Sequence comprises diverse metavolcanic and metasedimentary rocks of upper amphibolite metamorphic grade. The Araxá Group, which lies to the southeast of the Chapada deposit (Fig. 1), comprises similar lithologies of slightly lower metamorphic grade (greenschist to epidote-amphibolite). Although the Araxá Group is similar to the Mara Rosa Sequence in that it unconformably overlies Archean rocks (RIBErRO FILHO, 1981), Araxá rocks have generally been assigned to the Uruacuano orogenic cycle $(1.4$ to $1.1 \mathrm{Ga})$ on the basis of dating of granitic bodies which cross cut them. Intrusive rocks are found in all of the above units and include gabbro, diorite, granodiorite, tonalite, granite, serpentinite, and mafic dikes.

While the São Francisco craton and the high-grade mobile belts of the Brazilian coast have been the subject of a considerable number of geochronological studies (JARDím de SÁ, et al., 1976; CORDANI \& IYER, 1979; CORDANI \& TEIXEIRA, 1979; WERNICK, 1981; CORDANI \& BRITO NEVES, 1982; BERNASCONI, 1983), 


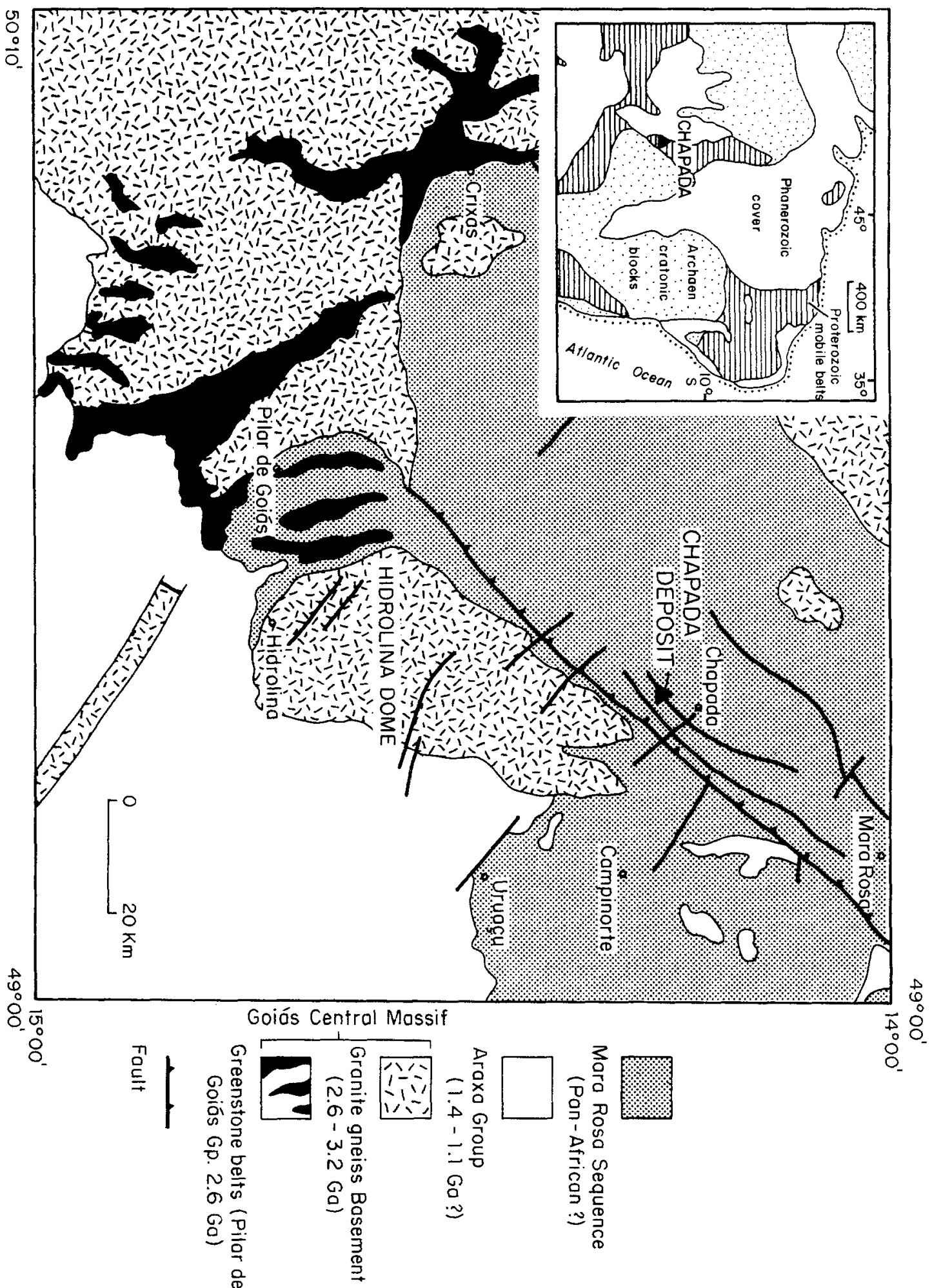

Fig. 1. Simplified geologic map of the Chapada region (after MACHADO, 1981 and RiBEIRO, 1981) showing distribution of local rock types. Inset shows location of the Chapada area (modified from RICHARDSON et al., 1986). 
largely due to their favorable exposures, only a few $\mathrm{Rb} / \mathrm{Sr}$ studies have been performed on rocks from the Tocantins province of central Brazil. A larger body of $\mathrm{K}$-Ar data exists for this region, but most $\mathrm{K}$-Ar dates reflect only the latest thermal event during the Brasiliano cycle and yield ages of 700 to $450 \mathrm{Ma}$. Ar. chean $\mathrm{Rb} / \mathrm{Sr}$ dates of 2.6 to $3.2 \mathrm{Ga}$ (HAsUI et al., 1980) have been obtained on granite-gneiss in the Goiás Central Massív, including the Hidrolina Dome (Fig. 1). Granitic intrusions that cross cut the Archean massifs and their surrounding mobile belts have yielded $\mathrm{Rb} / \mathrm{Sr}$ ages from 2000 to $520 \mathrm{Ma}$, with intrusions related to the Brasiliano cycle clustering at 700 to $520 \mathrm{Ma}$ (HASUI et al., 1980). Initial ${ }^{87} \mathrm{Sr} /{ }^{86} \mathrm{Sr}$ (I) values of these Brasiliano granitoids range from 0.706 to 0.760 and indicate vary. ing degrees of crustal contamination and/or reworking. Chapada lies south of the area where most PanAfrican/Brasiliano $\mathrm{Rb} / \mathrm{Sr}$ ages have been obtained.

\section{Analytical Procedures}

Thirteen whole rock samples and nine mineral separates from the Chapada deposit were analyzed in this study. All samples but one, PCC-12, were taken from drillholes intersecting the mineralized schists at depth and therefore are free from the effects of weathering. An effort was made to sample apparently correlative lithologies from closely spaced drillholes in order to increase the probability of obtaining a cogenetic rock suite. Conventional methods were used for the preparation of whole rock samples. Mineral fractions were obtained by combinations of magnetic, heavy liquid, and hand picking separation techniques. Whole rock samples were powdered before analysis, while mineral separates were not further pulverized following separation. Strontium isotopic analyses were made at CONOCO, Inc. on a Varian ${ }^{\circledR}$ MAT 260 thermal

\begin{tabular}{|c|c|c|c|c|c|}
\hline Sample & Description & $\underline{R b^{a}}$ & $\underline{s r^{a}}$ & ${ }^{87} \mathrm{Rb} /{ }^{86} \mathrm{Sr}$ & ${ }^{87} s r /^{86} s r^{b}$ \\
\hline $4-100$ & Muscovite schist & $124 \pm 1.8$ & $68 \pm 1.5$ & $5.295 \pm 0.14$ & $0.74672 \pm 0.00008$ \\
\hline $12-40^{d}$ & Pegmatite & $201 \pm 2.28$ & $80 \pm 1.21$ & $7.33 \pm 0.14$ & $0.79006 \pm 0.00004$ \\
\hline $30-80^{d}$ & Amphibolite & $8 \pm 1.09$ & $475 \pm 6.1$ & $0.049 \pm 0.007$ & $0.70402 \pm 0.00004$ \\
\hline $31-80$ & Biotite schist & $94 \pm 2.93$ & $177 \pm 4.0$ & $1.538 \pm 0.059$ & $0.71611 \pm 0.00002$ \\
\hline $38-78$ & Amphibolite & $13 \pm 0.6$ & $418 \pm 6.9$ & $0.090 \pm 0.004$ & $0.70487 \pm 0.00002$ \\
\hline $41-65.2$ & Biotite schist & $115 \pm 2.36$ & $73 \pm 1.91$ & $4.572 \pm 0.152$ & $0.74049 \pm 0.00003$ \\
\hline $44-79.6$ & Biotite schist & $71 \pm 1.90$ & $105 \pm 3.30$ & $1.958 \pm 0.081$ & $0.71981_{ \pm} 0.00002$ \\
\hline $59-68.8^{\mathrm{d}}$ & Pegmatite & $230 \pm 3,88$ & $72 \pm 0.86$ & $9.314 \pm 0.192$ & $-/ 78840 \pm 0.00003$ \\
\hline $63-80$ & Amphibolite & $131 \pm 2.9$ & $127 \pm 2.03$ & $2.990 \pm 0.082$ & $0.72870 \pm 0.00004$ \\
\hline $64-80$ & Biotite schist & $89 \pm 3.24$ & $360 \pm 5.4$ & $0.715 \pm 0.028$ & $0.70933 \pm 0.00005$ \\
\hline $87-80 B^{C}$ & Biotite & $210 \pm 1.7$ & $367 \pm 6.3$ & $1.657 \pm 0.031$ & $0.71713 \pm 0.00003$ \\
\hline $87-80 M^{C}$ & Muscovite & $132 \pm 3.7$ & $324 \pm 6.4$ & $1.180 \pm 0.040$ & $0.71655 \pm 0.00003$ \\
\hline $87-80 P^{C}$ & Plagioclase & $46 \pm 1.1$ & $399 \pm 4.6$ & $0.334 \pm 0.009$ & $0.70834 \pm 0.00003$ \\
\hline $87-80 W^{d}$ & Biotite schist & $75 \pm 2.4$ & $402 \pm 5.6$ & $0.540 \pm 0.019$ & $0.70933 \pm 0.00001$ \\
\hline $88-79 B^{C}$ & Biotite & $216 \pm 5.6$ & $97 \pm 1.9$ & $6.472 \pm 0.210$ & $0.75490 \pm 0.00001$ \\
\hline $88-79 M^{C}$ & Muscovite & $152 \pm 2.1$ & $116 \pm 2.6$ & $3.801 \pm 0.100$ & $0.73509 \pm 0.00003$ \\
\hline $88-79 P^{C}$ & Plagioclase & $37 \pm 1.7$ & $82 \pm 2.4$ & $1.306 \pm 0.071$ & $0.71569 \pm 0.00002$ \\
\hline $88-79 W R$ & Muscovite schist & $93 \pm 2.5$ & $153 \pm 4.0$ & $1.760 \pm 0.066$ & $0.71871 \pm 0.00003$ \\
\hline$P C C-12 B^{C}$ & Biotite & $163 \pm 2.7$ & $237 \pm 7.6$ & $1.99 \pm 0.07$ & $0.71892 \pm 0.00002$ \\
\hline$P C C-12 H^{d}$ & Hornblende & $24 \pm 1.8$ & $51 \pm 1.3$ & $1.36 \pm 0.11$ & $0.71141 \pm 0.00002$ \\
\hline$P C C-12 P^{C}$ & Plagioclase & $18 \pm 0.9$ & $819 \pm 8.3$ & $0.064 \pm 0.003$ & $0.70463 \pm 0.00002$ \\
\hline PCC-WR & Foliated diorite & $63 \pm 2.0$ & $471 \pm 4: 9$ & $0.387 \pm 0.013$ & $0.70717 \pm 0.00003$ \\
\hline
\end{tabular}

Table 1. Isotopic $\mathrm{Rb} / \mathrm{Sr}$ data for Chapada whole rock and mineral samples. Superscripts: $\mathrm{a}$ - values in $\mathrm{ppm}$; $\mathrm{b}$ - analytical error less than $0.01 \%$ (2 sigma); $c$ - mineral separate; $d$ - isochron outlier. All samples normalized To E\&A 0.70800 . 
ionization mass spectrometer. A rhenium double-filament arrangement was used in the evaporation-ionization process and measurements were made with double Faraday collectors. The standard deviation for the analyses was usually within $\pm 0.00004(2 \Varangle)$. During the course of this study, six independent determinations of the $\mathrm{E} \& \mathrm{~A}$ standard gave an ${ }^{87} \mathrm{Sr} /{ }^{86} \mathrm{Sr}$ (I) of $0.70807 \pm 0.00004(2 \Varangle)$. Rubidium and strontium concentrations were determined by X-ray fluorescence using an ORTEC TEFA system. Replicate analyses indicate a precision of approximately two percent. $\mathrm{Rb}$ and $\mathrm{Sr}$ concentrations and $\mathrm{Sr}$ isotopic determinations of analyzed rocks and minerals are show in Table 1.

\section{Strontium Isotopic Composition of Chapada Rocks and Minerals}

A whole rock isochron calculated for eight metavolcanic rocks from Chapada defines an isochron age of $561 \pm 9 \mathrm{Ma}$ with an I value of $0.70414 \pm 0.00005$ (2丈) (Fig. 2A). Although a biotite schist, $87-80$, and an amphibolite, 30-80, were excluded from this isochron because of their slight statistical deviation from the isochron calculated from the other eight samples, these samples clearly lie close to the calculated isochron, and are undoubtedly cogenetic with the eight host rocks constituting the isochron. Neither rock is lithologically different from other rocks on the isochron and they are not chemically altered or weathered. 'Two pegmatite samples fall above the isochron and are probably younger anatectic melts developed during the metamorphic event (discussed below) at $532 \pm 1 \mathrm{Ma}$ which followed formation of the host rocks. When the diorite whole rock sample, PCC-12, is included with the host schists, a calculated whole rock isochron age $560 \pm 8 \mathrm{Ma}$ with an I value of $0.70413 \pm 0.00004$ is obtained, values which are indistinguishable from those of the whole rock isochron calculated from the host schists alone. However, for reasons discussed below, we have chosen to leave the diorite off the whole rock isochron. A plot of $1 / \mathrm{Sr}$ versus a back-calculated ${ }^{87} \mathrm{Sr} /{ }^{86} \mathrm{Sr}$ value at $561 \mathrm{Ma}$ for each sample shows no

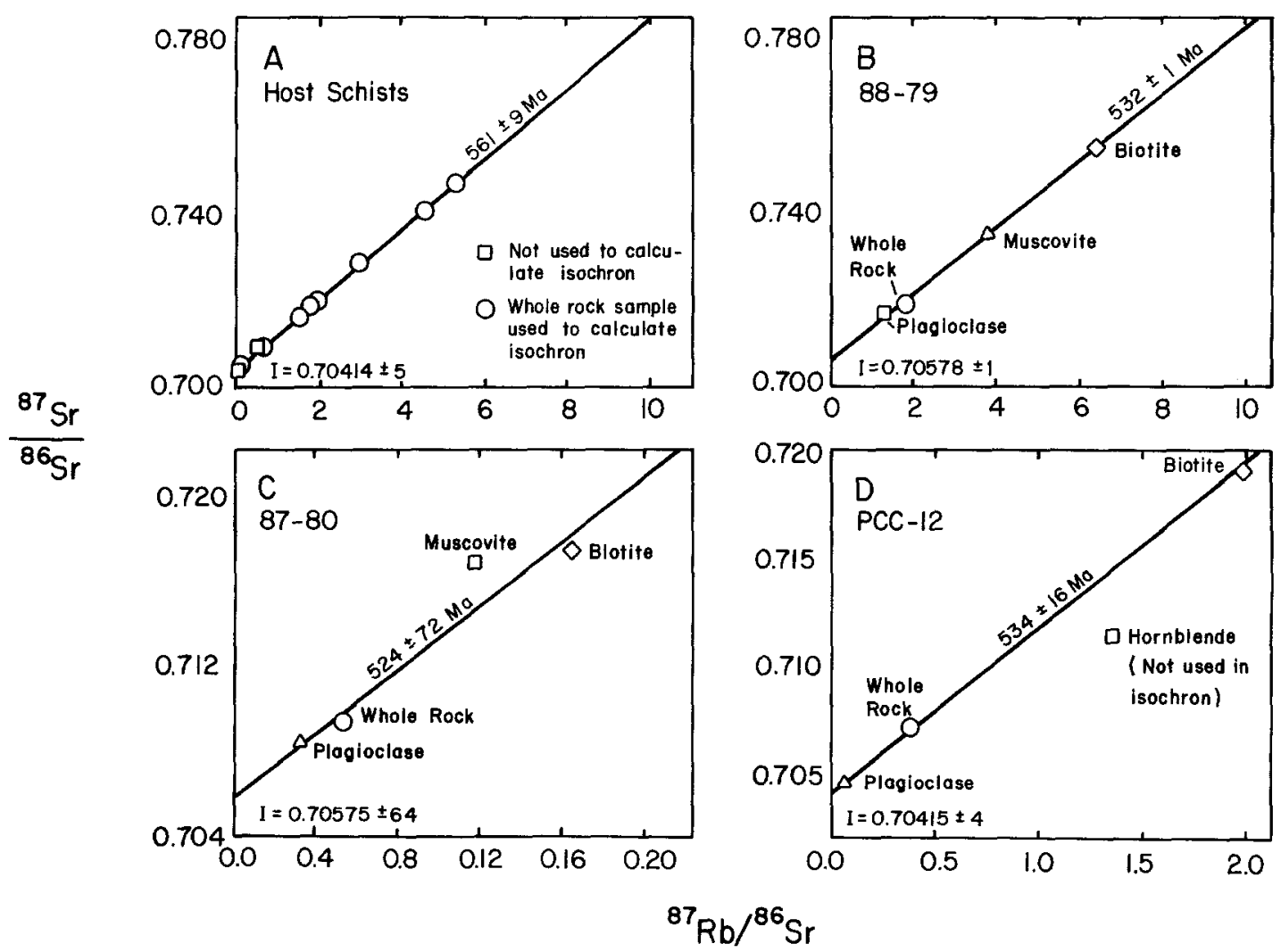

Fig. 2. A. Whole rock isochron for Chapada rocks. Isochron outiliers are pegmatites inferred to have formed during metamorphism. This and accompanying isochrons were calculated using a computer program (FAURE, 1977) based on equation 6 of YORK (1969). B. Mineral isochron, sample 88-79. C. Mineral isochron, sample 87-80. D. Mineral isochron, sample PCC-12. As discussed in the text, the hornblende fraction is not included in this isochron. 
correlation and indicates that the rocks did not form by mixing of two Sr isotopic sources.

Mineral isochrons were determined for three rocks at Chapada to assess the age of metamorphism (Figs. 2B, 2C, 2D). Two biotite schists, $87-80$ and $88-79$, are from within the deposit and PCC-12 is a sample of the adjacent diorite. The best constrained mineral isochron is from sample $88-79$, a biotite schist which falls on the whole rock isochron. This mineral isochron gives an age of $532 \pm 1 \mathrm{Ma}$ with an I value of $0.70578 \pm 0.00001$ (Fig. 2B). The other schist mineral isochron $(87-80)$, which deviated slightly from the whole rock isochron, is not as well constrained. It gives an age of $524 \pm 72 \mathrm{Ma}$, with an I value of $0.70575 \pm$ 0.0006 . This deviation probably reflects incomplete isotopic homogenization during metamorphism. The age of the mineral isochron for sample $88-79,532 \mathrm{Ma}$, probably indicates the time of the latest thermal event to have affected these rocks. The temperature of $650 \pm$ $20^{\circ} \mathrm{C}$ which we have determined for peak metamorphism at Chapada (RICHARDSON et al., 1986) should have reset all minerals in the schists to the same I value. The diorite (PCC-12) yields an isochron for the whole rock, and plagioclase and biotite fractions, although the hornblende fraction does not fall on this line (Fig. 2D). We have no petrographic justification for omitting the horrblende, although the similarity of the whole rock-plagioclase-biotite isochron to the other mineral isochrons discussed above suggests to us that it should be excluded. Note that the resultant whole rock-plagioclase-biotite isochron has an I value, $0.70415 \pm 0.00004$, which is identical to that of the whole rock isochron, but an age, $534 \pm 16 \mathrm{Ma}$, which is indistinguishable from that of metamorphism, $532 \pm$ $1 \mathrm{Ma}$.

The relatively low I value of $0.70414 \pm 0.00005$ for the whole rock isochron suggests that the Chapada metavolcanic rocks were not derived from melting of older Precambrian crustal material. If, for example, they represented remelted mid-Proterozoic crustal material, even with a very low I value, such as 0.701 , using an assumed $\mathrm{Rb} / \mathrm{Sr}$ value of 1.8 , their I value at 561 Ma would be around 0.73 , far above the value observed here. The calculated I values for the biotite schist mineral isochrons, $0.70578 \pm 0.00001$ and $0.70575 \pm$ 0.0006 are consistent with evolution from their original value of $0.70414 \pm 0.00005$ over the twentynine million years between formation at $561 \mathrm{Ma}$ and metamorphism at $532 \mathrm{Ma}$. In the case of the diorite it is difficult to determine whether the mineral isochron age of $534 \pm 16 \mathrm{Ma}$ represents the age of formation or the age of metamorphism. Because of the obvious folded and foliated nature of the diorite, we know it has been dynamically metamorphosed. We also know from mineralogical and trace element data that the diorite is related to the surrounding schists (RICHARDSON et al., 1986). However from thin section examination of diorite samples, it is clear that there has not been extensive recrystallization during metamorphism; plagioclase is found as one centimeter-long zoned andesine phenocrysts, and some diorite samples contain igneous clinopyroxene. The plagioclase, hornblende, and biotite separated from the diorite for analysis were probably original magmatic phases as well (GILL, 1981). The close similarity of the diorite I value, $0.70415 \pm 0.00004$, to that of the host schists, $0.70414 \pm 0.00005$, suggests that the diorite was derived from the same relatively primitive isotopic reservoir and not from melting of older Precambrian upper crustal material. This observation, coupled with the presumed original magmatic nature of the diorite mineralogy, suggests that the diorite mineral isochron represents its age of formation, and not a metamorphic event which followed its formation at a significantly later date. If the diorite had formed considerably before metamorphism, its I value would have had to have been very primitive, and its $\mathrm{K}_{2} \mathrm{O}$ abundance much lower than the observed 1.50 weight percent, to permit its evolution to the relatively primitive value, 0.70415 \pm 0.00004 , indicated by the isochron, assuming isotopic rehomogenization during metamorphism. Conversely, if the diorite had intruded with an I value equal to that of the host schists, 0.70414 , significantly before metamorphism, its I value would be higher than indicated, again assuming isotopic rehomogenization during metamorphism. If we make the reasonable assumption that the diorite stock acted as a competent bulwark during metamorphism and that recrystallization and isotopic rehomogenization did not occur, as is indicated petrographically, a scenario involving diorite emplacement sometime between formation of the host schists at $561 \pm 1 \mathrm{Ma}$ and metamorphism at $532 \pm 1 \mathrm{Ma}$, become plausible. As mentioned previously, the diorite does fall on the whole rock isochron. However, this could be fortuitous and it is unlikely that the diorite was emplaced long before metamorphism, as the folded and foliated nature of the diorite in outcrop suggests a synorogenic origin.

\section{Relation of Chapada Ages to Geochronology of Central Brazil}

The indicated age of formation of the rocks at Chapada, $561 \pm 9 \mathrm{Ma}$, contradicts the previously assigned early to mid-Proterozoic age for the Mara Rosa Sequence (RIBEIRo FILHO, 1981). Either the host schists at Chapada do not belong in the Mara Rosa Sequence, or the Mara Rosa Sequence is actually much younger 
and related to volcanism and plutonism associated with the Brasiliano cycle (700-450 Ma). Our field work in the vicinity of Chapada did not permit a distinction to be made between Chapada rocks and the surrounding Mara Rosa Sequence, as both appeared lithologically similar and equally metamorphosed. Thus, we cannot say, at this time, whether our age data for Chapada should be extended to the entire Mara Rosa Seculence.

The significance of our results to regional geochronological relations lies in the recognition of PanAfrican/Brasiliano magmatic activity of a type not previously seen in this area. Pan-African/Brasiliano granitoids with I values less than 0.710 are found in the northern part of the Brasilia-Uruacu belt, but were not known as far south as Chapada. A Rb/Sr geochronological study near Chapada (HASUI et al., 1980) has identified rocks of Pan-African/Brasiliano age (550 Ma) with I value of 0.760 , indicating at least partial reworking of continental crust. However, the magmatism represent by the Chapada deposit is not related simply to rejuvenation of older basement rocks; its I values are too low to permit extensive crustal residence. Our Sr isotopic results from Chapada indicate not only a thermal event at this time but also chemically primitive, arc-related calc-alkaline andesitic magmatism. This ac- tivity within the Brasilia-Uruacu mobile belt may represent cratonization of the South American continent. Calc-alkaline andesitic magmatism related to subduction was also occuring in northeast Africa during this time and has been suggested as an important factor in cratonization there (GASS, 1982). In addition, the recognition of Pan-African/Brasiliano magmatic activity may be of possible metallogenetic significance in that we know, from our investigation of the Chapada deposit (RICHARDSON et al., 1986), that high level granitoids of the age and type represented by Chapada are mineralized in this area of Brazil and constitute an important target for mineral exploration.

\section{Acknowledgements}

We wish to thank Noranda Exploration Co., Ltd. of Toronto for their sponsorship of the research reported on here. Dr. David J. T. Carson of Noranda Exploration initiated the thesis research project, of which this paper forms a segment, and arranged for it to be carried out. We are grateful to CON. OCO Inc., Ponca City, Oklahoma, for permission to carry out the isotopic analyses in their laboratory and to an anonymous reviewer for Geologische Rundschau for comments that clarified the presentation.

\section{References}

Ayres, L. D. \& Cerny, P. (1982): Metallogeny of granitoid rocks in the Canadian Shield. - Can. Miner. 20, $439-536$.

BARLEY, M. E. (1982): Porphyry-style mineralization associated with early Archean calc-alkaline igneous activity, eastern Pilbara, western Australia. - Econ. Geol., 77, $1230-1236$.

BERNASCONI, A. (1983): The Archean terranes of central eastern Brazil: a review. - Precambrian Res. 23, 107-131.

CoRdANI, U. G. $\&$ Brito Neves, B. B. (1982): The geologic evolution of South America during the Archean and Early Proterozoic. - Rev. Bras. Geoc., 12, 78-88.

- \& IYER, S. S. (1979): Geochronological investigations on the Precambrian granulitic terrain of Bahia, Brazil. Precambrian Res., 9, 255-274.

- \& TetxeirA, W. (1979): Comentários sobre as determinacoes geocronologicas existentes para as regioñes das Folhas Rio de Janeiro, Vitorio e Iguape. - Dep. Nac. Prod. Mineral, Carta Geol. do Brasil, Folhas SF-23, SF-24, and SG-23, pp. 175-207.

Danni, J. C. M., Fuck, R. A. \& Leonardos, O. H. (1982): Archaean and Lower Proterozoic units in central Brazil. - Geol. Rundsch. 71, 291-317.

FAURe, G. (1977): Principles of isotope geology. - John Wiley, New York.

FORTEY, N. J. (1980): Hydrothermal mineralization associated with minor late Caledonian intrusions in northern
Britain: preliminary comments. - Trans. Instn. Min. Metall. (Sect. B: appl. earth sci.), 89, B173-B176.

GAAL, G. \& IsOHANNI, M. (1979): Characteristics of igneous intrusions and various wall rocks in some Precambrian porphyry copper molybdenum deposits in Pohjanmaa, Finland. - Econ. Geol., 74, 1198-1211.

Gass, I. G. (1982): Upper Proterozoic (Pan-African) calc-alkaline magmatism in north-eastern Africa and Arabia. In: R: S. Thorpe (Editor), Andesites-Orogenic andesites and related rocks, John Wiley, New York, 591-611.

GILL, J. B. (1981): Orogenic andesites and plate tectonics, v. 16. - In: Wyllie, P. J. (Editor in Chief), Minerals and rocks, Springer-Verlag, New York.

Hasui, Y., Tassinari, C. C. G., Junior, O. S., TeixeIra, W., AlmeIDA, F. F. M. DE \& KAWASHITA, K. (1980): Datacoes Rb-Sr e K-Ar do centronorte do Brasil e seu significado geologico-geotectonico. - An XXXI Cong. Bras. de Geol., 5, 2659-2676.

JaRdím, de SÁ, E. F., Mcreath, I. Brtto Neves, B. B. \& Bartels, R. L. (1976): Novos dados geocronologicos sobre a Craton Sao Francisco no Estado da Bahia. - An. 29th Congr. Bras. Geol. Abstr., p. 204.

MaCHADO, E. C. (1981): Novas consideracoñes e intergracaño geologica na regiaño de Pilar-Crixas/Mara Rosal-Porangatu, in $1^{\circ}$ Simposio de geologia do centrooeste, Outubre 1981, Goiania. - Soc. Bras. Geol., Nucleos Goiânia e Brasilia, p. 281-299. 
PORADA, H. (1979): The Damara-Ribeiro orogen of the PanAfrican-Brasiliano cycle in Namibia (South Africa) and Brazil as interpreted in terms of continental collision. Tectonophysics 57, 237-267.

RIBEIRO, FILHO, W. (1981): Reavaliacao da geologia de PilarMara Rosa. - In: $1^{\circ}$ Simposio de geologia do centro-oeste, Outubre 1981, Goiania e Brasilia, 281-299.

RichaRdSON, S. V., KeSLER, S. E. \& ESSENE, E. J. (1986): Origin and geochemistry of the Chapada deposit, Brazil: A metamorphosed wall rock porphyry copper deposit. Econ. Geol., 81, 1884-1898.
WAKEFIELD, J. (1978): Samba: A deformed porphyry-type copper deposit in the basement of the Zambian copperbelt. - Trans. Inst. Mining Metall. (Sect. B: Appl. Earth Sci.) $87, \mathrm{~B} 43-\mathrm{B} 52$

WernicK, E. (1981): The Archean of Brazil. - In: J. M. Mabesoome, B. B. Brito Neves and A. N. Sial (Editors), The Geology of Brazil. Earth-Sci. Rev. 17, 31-48.

YORK, D. J. (1969): Least squares fitting of a straight line with correlated errors. - Earth and Planetary Sci. Letters, 5, $320-324$. 